\title{
Analysis of $\mathrm{T}$ cell subsets present in the peripheral blood and synovial fluid of reactive arthritis patients
}

\author{
Helen Beacock-Sharp, Joyce L Young, J S Hill Gaston
}

\begin{abstract}
Objective-Reactive arthritis $(\operatorname{ReA})$, a HLA-B27 associated arthropathy, develops in susceptible people after infection with certain bacteria. $T$ cells have been implicated in the pathogenesis of the arthritis but which of the different subsets is involved is still debated. This study has further elucidated the role of the $\mathrm{CD}^{+}$and $\mathrm{CD8}^{+} \mathrm{T}$ cells by examining the expression of various surface markers associated with activation.

Methods-Three colour flow cytometry was used to examine the phenotype of the $T$ cells within the synovial fluid (SF) and peripheral blood (PB) of ReA patients. Results-ReA SF, compared with paired $P B$, contained a higher percentage of $\mathrm{CD} \mathrm{69}^{+}, \mathrm{CD}^{+} 5^{+}$, and $\mathrm{HLA}_{-} \mathrm{DR}^{+} \mathrm{CD}^{+}{ }^{+} \mathrm{T}$ cells. The majority of $S F T$ cells also expressed the putative memory marker CD45RO. Within the T cell subsets, CD25 was expressed primarily on the $\mathrm{CD}^{+} \mathrm{T}$ cells; however more $\mathrm{CD8}^{+} \mathrm{T}$ cells were HLA-DR ${ }^{+}$.

Conclusion-The results show that both $\mathrm{CD4}^{+}$and $\mathrm{CD8}^{+} \mathrm{T}$ cell populations demonstrate evidence of recent activation. Whether these cells are involved in inducing inflammation, regulating the inflammation, or have become active as a result of migration through the endothelium, remains to be determined by functional studies.
\end{abstract}

(Ann Rheum Dis 1998;57:100-106)

Reactive arthritis ( $\operatorname{ReA})$ develops in susceptible people after infection with various facultative (for example, yersinia and salmonella) or obligate (chlamydia) intracellular pathogens. The precise mechanisms underlying the disease are unknown but $\mathrm{T}$ cells are proposed to be involved. Immunohistochemistry has identified lymphocytes and neutrophils as the predominant cell types infiltrating the inflamed joint, ${ }^{1}$ and further analysis of the mononuclear cell (MC) populations isolated from the synovial fluid (SF) show that the majority of these are $\mathrm{T}$ lymphocytes, with some monocytes but very few $\mathrm{B}$ cells. ${ }^{2}$ There is also a strong association of the disease with the MHC class I molecule, HLA-B27, which presents intracellular antigens to $\mathrm{CD}^{+} \mathrm{T}$ cells. Additional evidence in favour of a role for $\mathrm{T}$ cells in the pathogenesis of ReA comes from the ability of SF derived T cells to proliferate in response to the organism that triggered the disease. ${ }^{34} \mathrm{~T}$ cells have also been implicated in causing the disease seen in an animal model of the HLA-B27 associated diseases that have been developed in Lewis rats. Rats that are transgenic for both HLAB27 and human $\beta 2$-microglobulin $(\mathrm{h} \beta 2 \mathrm{M})$, and express these at the cell surface, spontaneously develop inflammatory disorders resembling the human spondyloarthropathy. ${ }^{5} \mathrm{~T}$ cells have been identified as having a pathogenic role in this animal model, as disease can be adoptively transferred to T cell deficient HLAB2 $7^{+}$nude rats, which do not otherwise develop symptoms, by $\mathrm{T}$ lymphocytes from transgenic rats. ${ }^{6}$

The role of the $\mathrm{CD} 4^{+}$and $\mathrm{CD} 8^{+} \mathrm{T}$ cell subsets in the pathogenesis of $\operatorname{ReA}$ is still debated. As HLA-B27 presents antigens to $\mathrm{CD}^{+} \mathrm{T}$ cells, a simple hypothesis proposes that arthritogenic peptides are being presented to these cells. In support of this hypothesis, $\mathrm{CD}^{+} \mathrm{T}$ cell clones cytolytic for HLA-B $27^{+}$targets pulsed with Yersinia enterocolitica and Salmonella typhimurium have been isolated from ReA SF by one laboratory. ${ }^{78}$ However, proliferative responses to the triggering organism are greatly diminished in SFMC depleted of $\mathrm{CD}^{+} \mathrm{T}$ cells, and chlamydia specific cytotoxicity was not detected in SFMC from patients with chlamydia induced arthritis. ${ }^{9}$ Conversely, $\mathrm{CD} 4^{+} \mathrm{T}$ cells isolated from SF can readily be induced to proliferate in response to the triggering bacterium and several organism specific $\mathrm{SF}$ derived $\mathrm{CD}^{+} \quad \mathrm{T}$ cell clones have been characterised..$^{10-13}$ In the animal model, $\mathrm{CD} 4^{+} \mathrm{T}$ cells have also been found to induce disease more rapidly and with more severe consequences than $\mathrm{CD}^{+} \mathrm{T}$ cells when the separate T cell subsets are transferred to nude HLAB27 ${ }^{+}$transgenic rats. ${ }^{6}$ Hence, other hypotheses have been proposed for the role of HLA-B27 in $\mathrm{ReA},{ }^{14}$ including the absence of a HLA-B27 restricted $\mathrm{CD} 8^{+} \mathrm{T}$ cell response, or presentation of a HLA-B27 derived peptide to $\mathrm{CD} 4^{+} \mathrm{T}$ cells.

One possible way of determining the relative importance of the $\mathrm{CD} 4^{+}$and $\mathrm{CD} 8^{+} \mathrm{T}$ cell subsets in the pathogenesis of $\operatorname{ReA}$, is to examine the phenotype of these cells within the joint. Upon stimulation $\mathrm{T}$ cells upregulate expression of activation markers in a defined sequence. ${ }^{15}$ Expression of these markers on the $\mathrm{T}$ cells isolated from the SF of ReA patients could demonstrate which $\mathrm{T}$ cells are being stimulated, and therefore more likely to be involved in the inflammatory process. These activation markers include CD69, CD25, and HLA-DR. CD69 is a member of the C-type 
Table 1 ReA patients studied

\begin{tabular}{llllll}
\hline Patient & $\begin{array}{l}\text { HLA-B27 } \\
\text { status }\end{array}$ & Sex & Age & Triggering organism & $\begin{array}{l}\text { Duration of } \\
\text { arthritis } \\
\text { (months) }\end{array}$ \\
\hline 1 & + & M & 20 & Enteric (Salmonella) & 5 \\
2 & + & M & 26 & Enteric & $<1$ \\
3 & + & M & 35 & Salmonella & $<1$ \\
4 & - & M & 48 & Chlamydia & 1 \\
5 & + & F & 48 & Shigella & 1 \\
6 & + & M & 18 & Chlamydia & 1 \\
7 & + & M & 21 & Salmonella & 2 \\
8 & + & M & 19 & GU (Chlamydia) & 3 \\
9 & - & M & 52 & GU (Chlamydia) & $<1$ \\
10 & - & M & 36 & Enteric & $<1$ \\
11 & ND & 20 & Salmonella & 1 \\
12 & - & F & 34 & Enteric & 2 \\
13 & - & M & 34 & Enteric & 1 \\
14 & + & M & 32 & Enteric (Yersinia) & 1 \\
\end{tabular}

$\mathrm{ND}=$ not determined. If the triggering organism could not be defined absolutely, the type of infection (that is, enteric or GU (genitourinary)) is noted with the suspected bacteria shown in parentheses.

Table 2 Monoclonal antibodies and secondary reagents used

\begin{tabular}{lll}
\hline Antibody & Isotype & Source \\
\hline CD3-BIO & IgG1 & Dako (High Wymcombe, Buckinghamshire, UK) \\
CD4-BIO & IgG1 & Dako \\
CD4-FITC & IgG1 & Dako \\
CD4-PE & IgG1 & Dako \\
CD8-PE & IgG1 & Dako \\
CD25-FITC & IgG1 & Dako \\
CD69-FITC & IgG1 & Dako \\
HLA-DR-FITC & IgG1 & Serotec (Kiddlington, Oxfordshire, UK) \\
TCR $\alpha$ ß-FITC & IgG1 & Becton Dickinson (Cowley, Oxfordshire, UK) \\
TCR $\gamma$-FITC & IgG1 & Becton Dickinson \\
CD45RA-FITC & IgG1 & Serotec \\
CD45RO-FITC & IgG2a & Serotec \\
Secondary reagents & - & Life Technologies (Paisley, Scotland) \\
Streptavidin-RED670 & - & \\
Negative controls & - & Dako \\
IgG1-FITC & - & Dako \\
IgG1-PE & - & Dako \\
IgG1-BIO & - & Dako \\
IgG2a-FITC & &
\end{tabular}

(calcium dependent) lectin superfamily, which is detectable at the cell surface within two to four hours of stimulation ${ }^{16}$ but is downregulated by 48 hours. CD25, the IL2 receptor $\alpha$ chain (IL2R $\alpha$ ), can also be detected at 24 hours, but peak expression is not until 72 hours. ${ }^{17}$ Finally, HLA-DR expression is upregulated by one week after stimulation and is detectable on the cell surface for several weeks. ${ }^{15}$ Expression of the different isoforms of CD45 may also provide an insight into the role of one particular $\mathrm{T}$ cell subset compared with the other. T cells that have not yet encountered antigen - that is, naive $\mathrm{T}$ cells-express high levels of CD45RA on their surface. However, once a $\mathrm{T}$ cell is stimulated, exons are spliced out and the majority of CD45 molecules expressed are of the RO isoform. ${ }^{18}$

To date, analysis of the phenotype of the cells found in the ReA joint has mainly used immunohistochemical techniques, which generally only allow two surface markers to be stained and do not allow characterisation of such large numbers of cells as flow cytometry. Analysis of the expression of activation markers has not been done specifically for $\mathrm{T}$ cells, but cells positive for CD25 and CD71 (transferrin receptor) have been found in ReA SFMC. ${ }^{19}$ Another study reported the number of SFMC expressing HLA-DR to be greater than the number of $\mathrm{CD}_{1} \mathrm{bb}^{+}$monocytes and $\mathrm{B}$ cells, ${ }^{2}$ with the difference most probably accounted for by activated $\mathrm{T}$ cells. To clarify the role of the $\mathrm{CD} 4^{+}$ and $\mathrm{CD}^{+} \mathrm{T}$ cell subsets in the pathogenesis of ReA, this study has defined the phenotype of the $\mathrm{T}$ cells in the ReA joint using three colour flow cytometry.

\section{Methods}

PATIENTS AND CONTROLS

Paired samples of heparinised peripheral blood (PB) and SF were collected from clinically characterised ReA patients, as shown in table 1. Patients were typed for HLA-B27 using a PCR based strategy, according to the method reported previously. ${ }^{20} \mathrm{~PB}$ was also obtained from eight normal controls, none of whom were HLA-B27 $7^{+}$.

\section{MONONUCLEAR CELL SEPARATION}

PB was diluted 1:1 in phosphate buffered saline (PBS) before centrifugation over Ficollhypaque (Pharmacia Biotech Ltd, St Albans, Hertfordshire, UK). Mononuclear cells were harvested from the interface of the ficoll and the plasma, washed in PBS, and either stained directly or cryopreserved in fetal bovine serum (Sigma Chemical Co, Poole, Dorset, UK) containing $10 \%$ dimethyl sulphoxide (Sigma) for future analysis.

\section{MONOCLONAL ANTIBODIES}

All the monoclonal antibodies used were directly conjugated to fluorescein isothiocyanate (FITC), phycoerythrin (PE), or biotin (BIO), as listed in table 2. The antibodies were used at the optimal concentration previously determined by titration. Biotin conjugated antibodies were detected using streptavidinRED670 (Life Technologies, Paisley, Scotland).

\section{FLOW CYTOMETRY}

PBMC and SFMC samples were divided into the appropriate number of samples containing at least $1 \times 10^{5}$ cells and washed in PBS containing $0.1 \%$ bovine serum albumin (Sigma) and $0.01 \%$ sodium azide (Sigma). All samples were labelled with anti-CD3-BIO in conjunction with anti-CD4-PE or anti-CD8-PE and an additional antibody specific for the appropriate surface marker conjugated to FITC. Cells were incubated in $100 \mu \mathrm{l}$ of the combinations of antibodies diluted in PBS for 30 minutes at $4^{\circ} \mathrm{C}$. After washing off excess antibody, streptavidin-RED670 was added for $30 \mathrm{~min}$ utes at $4^{\circ} \mathrm{C}$ and then the cells washed again. Immunofluorescence was detected with a Becton Dickinson FACSort flow cytometer. Samples were gated on forward and side scatter to exclude dead cells. As the detectable emission spectra of the fluorochromes overlap slightly, cells were separately labelled with a single antibody conjugated to each fluorochrome and the flow cytometer compensated to ensure that the fluorochrome was only detected by single detector. Data were analysed using WinMDI Version 2 (Trotter@scripps.edu). The analysis was limited to $\mathrm{T}$ cells by excluding any cells that did not express CD3. T cells were scored positive for each surface marker if fluorescence was above that detected using an isotype matched negative control antibody. 


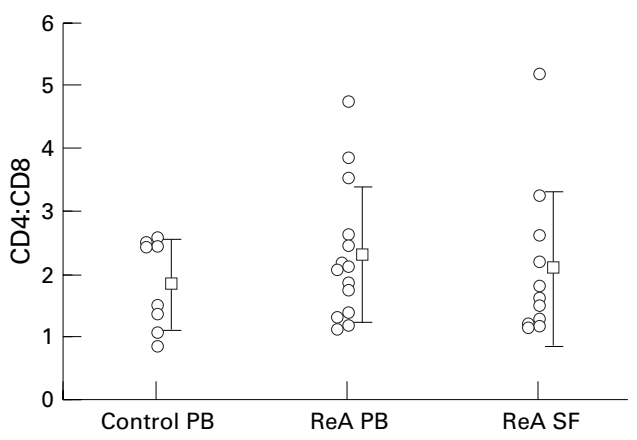

Figure 1 CD4:CD8 ratio of $T$ cells from control and ReA $P B$, and from ReA SF. The CD4:CD8 ratio of $C D 3^{+} T$ cells isolated from $P B$ or $S F$, or both, of control subjects and ReA patients is shown. Each data point represents one person, and the mean (SD) for each cohort is shown.

STATISTICAL ANALYSIS

The statistical significance of the results was determined using the Wilcoxon signed rank test for paired samples, or the Mann-Whitney test for unpaired samples.

\section{Results}

T CELL SUBSETS

To investigate the possibility of selective recruitment of one of the subsets of $\mathrm{T}$ cells into the joint, the ratio of $\mathrm{CD}^{+}$and $\mathrm{CD} 8^{+}$cells within the $\mathrm{CD}^{+} \mathrm{T}$ cell population of the $\mathrm{PB}$ and SF of ReA patients, and in PB from healthy controls was analysed (fig 1). The mean (SD) CD4:CD8 ratios of control $\mathrm{PB}, \mathrm{ReA} \mathrm{PB}$, and ReA SF were 1.84 (0.72), 2.24 (1.07), and 1.99 (1.23), respectively. None of these differs significantly from each other, nor from the reported mean CD4:CD8 ratio of 468 healthy blood donors $(2.13(1.04)) .{ }^{21}$ Patient 13 had a very high SF CD4:CD8 ratio (5.2), but this was not reflected in the paired PB (CD4:CD8 $=2.1$ ).

The number of $\mathrm{CD}^{+} \mathrm{T}$ cells expressing the $\alpha \beta$ TCR and $\gamma \delta$ TCR in ReA PB and SF was analysed (fig 2). Although some ReA patients had a small increase in the number of TCR $\gamma \delta^{+}$
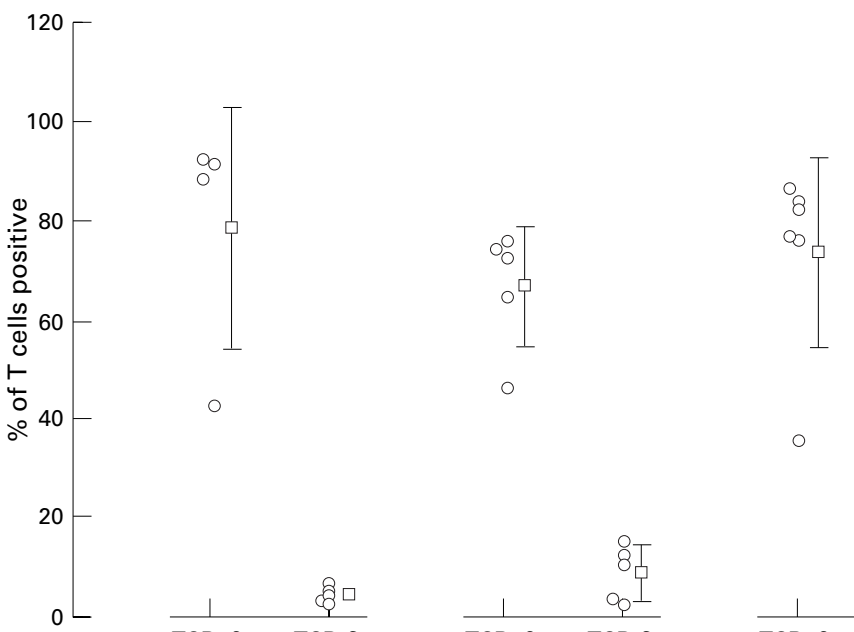

$\circ$
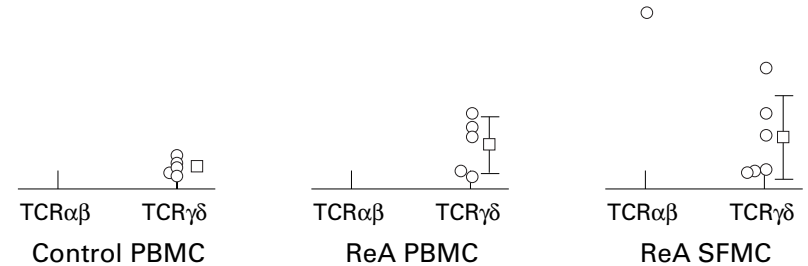

Figure 2 TCR expression in control and ReA PB, and ReA SF. The percentage of $C D 3^{+}$ $T$ cells expressing the $\alpha \beta T C R$ and the $\gamma \delta T C R$ is shown. Each data point represents one individual, and the mean (SD) for each cohort is shown.
$\mathrm{T}$ cells in their SF compared with paired PB, this difference was not significant when the cohort was analysed as a whole. TCR expression by PB T cells from ReA patients was also compared with that from control $\mathrm{PB}$ and no significant difference was found.

CD45 EXPRESSION

Expression of the different isoforms of CD45 is thought to differ in memory and naive $\mathrm{T}$ cell subsets. Cells that have not previously encountered antigen express predominantly CD45RA, whereas after stimulation most $T$ cells are $\mathrm{CD} 45 \mathrm{RO}^{+}{ }^{18} \mathrm{~A}$ high proportion $(67.7 \%(13.0 \%))$ of the $\mathrm{CD}^{+} \mathrm{T}$ cells in the $\mathrm{PB}$ of both controls and $\operatorname{ReA}$ patients were found to be CD45RA (fig 3). However, fewer of the $T$ cells isolated from the SF of ReA patients expressed this molecule. Instead, the majority of these $\mathrm{T}$ cells $(73.6 \%$ (17.7\%)) were found to express CD45RO, the low molecular weight form of the CD45 molecule, associated with activated and memory $T$ cells. Patient 12 had very high percentages of CD45RA ${ }^{+} \mathrm{T}$ cells, and a lower proportion of $\mathrm{CD}_{45 \mathrm{RO}^{+}} \mathrm{T}$ cells, in both $\mathrm{PB}$ and SF. However, there was still an increase in the number of $\mathrm{CD} 45 \mathrm{RO}^{+} \mathrm{T}$ cells in the SF when compared with the PB. The differences in the number of $\mathrm{CD}_{45 \mathrm{RA}^{+}}$and CD45RO ${ }^{+} \mathrm{T}$ cells in ReA PB compared with $\mathrm{SF}$ did not reach significance $(\mathrm{p}=0.0625$ for both CD45RA and CD45RO). More patients need to be analysed to determine whether this trend would achieve statistical significance.

Analysis of the expression of CD45RA and $\mathrm{CD} 45 \mathrm{RO}$ on the $\mathrm{CD}^{+}$and $\mathrm{CD}^{+}$subsets of $\mathrm{T}$ cells (fig 4) showed that more of the $\mathrm{CD}^{+}{ }^{+} \mathrm{T}$ cells expressed CD45RO. This difference was significant in $\operatorname{ReA} S F(p=0.03)$ and in the combined control and ReA PB samples $(\mathrm{p}=0.05)$. Conversely, more of the $\mathrm{CD}^{+} \mathrm{T}$ cells were found to express CD45RA (ReA SF $\mathrm{p}=0.03$, combined PB $\mathrm{p}=0.004)$. A significant difference was not found if the results from control and ReA PB were analysed independently, possibly a reflection of the comparatively small number of samples studied.

ACTIVATION MARKERS

Expression of activation markers on $\mathrm{T}$ cells is indicative of recent stimulation and therefore may be evidence that these $T$ cells are involved in the pathogenesis of the arthritis. ReA PB was found to contain more HLA-DR ${ }^{+} \mathrm{T}$ cells than control PB ( $p=0.05)$ (fig $5 \mathrm{C})$, but there were no significant differences between control and ReA PB in the number of $\mathrm{T}$ cells expressing CD69 or CD25. ReA SF was found to contain more $\mathrm{CD}^{+} \mathrm{T}$ cells expressing CD69, CD25, and HLA-DR, when compared with ReA PB $(p<0.0001$ for each activation marker) (fig 5). When this increased expression of activation markers was analysed in the $\mathrm{CD} 4^{+}$and $\mathrm{CD} 8^{+} \mathrm{T}$ cell subsets, a significantly higher percentage of both $\mathrm{CD}^{+}$and $\mathrm{CD}^{+} \mathrm{T}$ cells within $\mathrm{ReA} \mathrm{SF}$, compared with paired $\operatorname{ReA} \mathrm{PB}$, expressed CD69 (CD4, p=0.002; CD8, p=0.003) and HLA-DR ( $p=0.001$ for both $\mathrm{CD}^{+}$and $\mathrm{CD}^{+}$ $\mathrm{T}$ cell subsets) (fig $6 \mathrm{~A}$ and $6 \mathrm{C}$, respectively). CD25 expression was significantly increased 

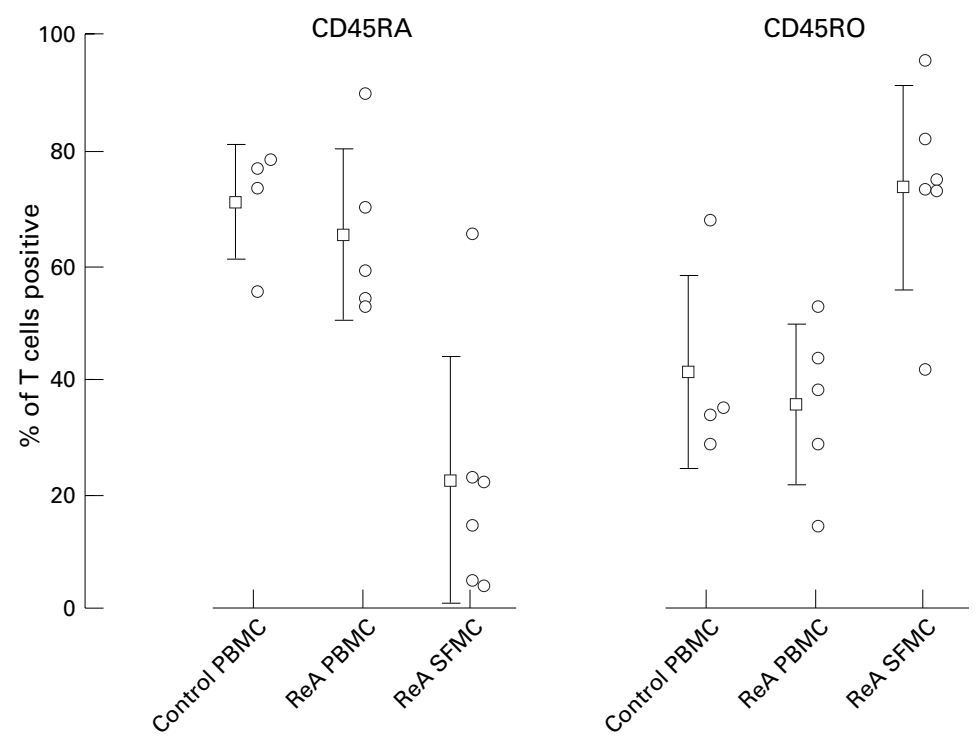

Figure $3 C D 45$ Expression on $P B$ and SF T cells. The percentage of $C D 3^{+} T$ cells expressing CD45RA and CD45RO is shown. Each data point represents one person and the mean (SD) for each group has been included.
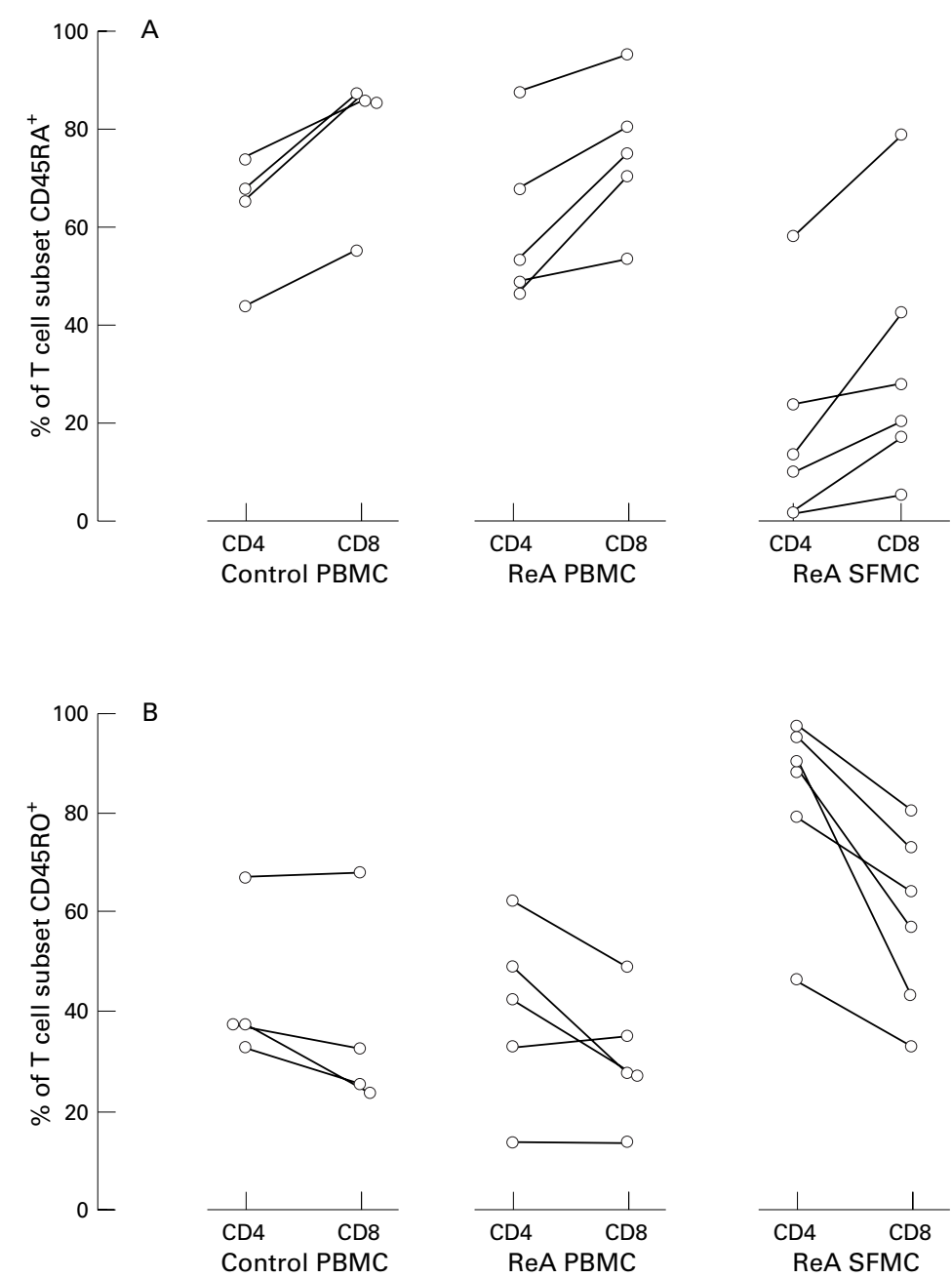

Figure 4 CD45 Expression on $T$ cell subsets. Expression of CD45RA (A) and CD45RO (B) on the $C D 4^{+}$and $C D 8^{+} T$ cell subsets is shown. Lines connect the two $T$ cell subsets isolated from the same person. on $\mathrm{CD}^{+} \mathrm{T}$ cells within ReA SF, compared with paired ReA PB ( $p=0.01)$; however, there was not a significant difference in the number of $\mathrm{CD} 8^{+} \mathrm{CD} 25^{+} \mathrm{T}$ cells (fig $6 \mathrm{~B}$ ).

In all populations tested (that is, control $\mathrm{PB}$, and $\mathrm{ReA} P B$ and $\mathrm{SF}$ ) a higher percentage of $\mathrm{CD} 4^{+} \mathrm{T}$ cells, compared with $\mathrm{CD} 8^{+} \mathrm{T}$ cells,

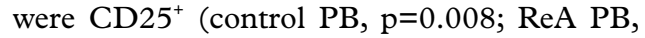
$\mathrm{p}=0.0001 ; \operatorname{ReA} S F, \mathrm{p}=0.0005$ ) (fig 6B). Analysis of HLA-DR expression in ReA SF showed that in most patients more $\mathrm{CD}^{+} \mathrm{T}$ cells than $\mathrm{CD} 4^{+} \mathrm{T}$ cells expressed this molecule, although this difference was not statistically significant $(\mathrm{p}=0.064)$. No differences in HLA-DR expression by the $\mathrm{CD} 4^{+}$and $\mathrm{CD} 8^{+} \mathrm{T}$ cell subsets were evident in control or ReA PB (fig 6C). Also, there were no differences in the proportion of $\mathrm{CD} 69^{+} \mathrm{T}$ cells in the $\mathrm{CD} 4^{+}$and $\mathrm{CD} 8^{+}$subsets in control PB, ReA PB or ReA SF (fig 6A).

Discussion

The association of ReA with HLA-B27 has led to the proposal that $\mathrm{CD}^{+} \mathrm{T}$ cells restricted by this allele may be involved in the pathogenesis
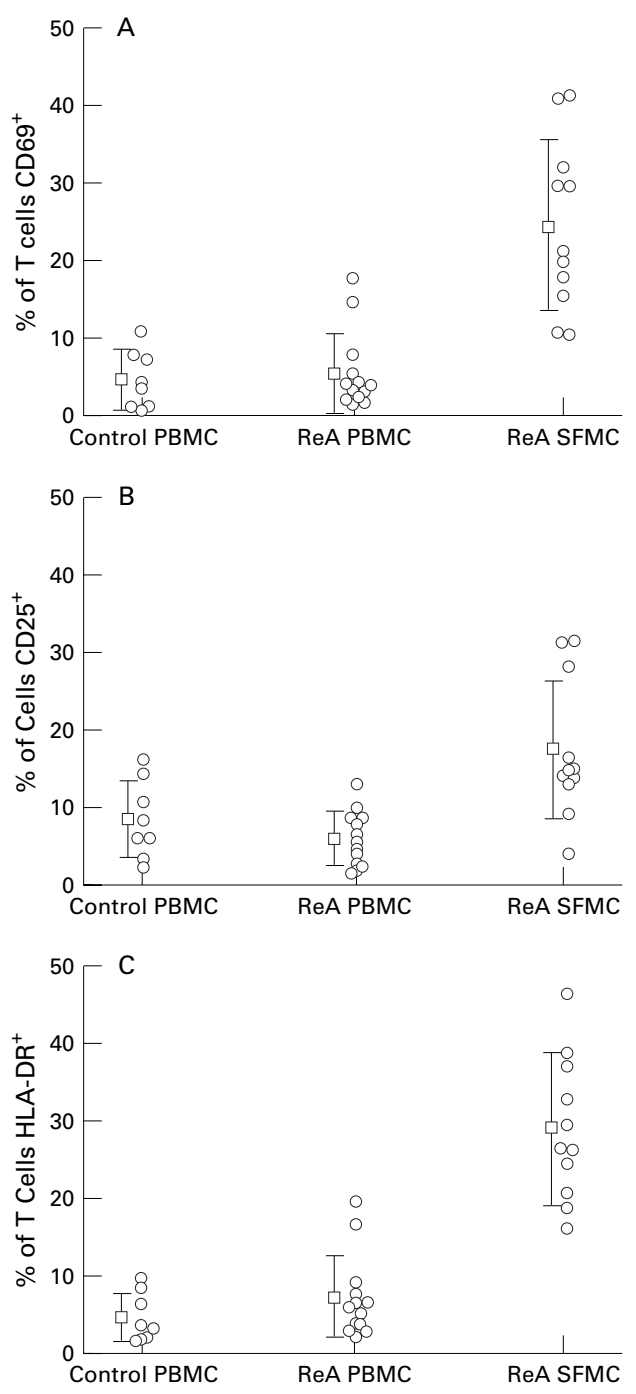

Figure 5 Expression of activation markers in $P B$ and SF The percentage of $C D 3^{+} T$ cells positive for $C D 69(A)$, $C D 25(B)$, and HLA-DR $(C)$ in control PB and ReA PB and $S F$ is shown. Each data point represents one person and the mean (SD) for each group has also been plotted. 

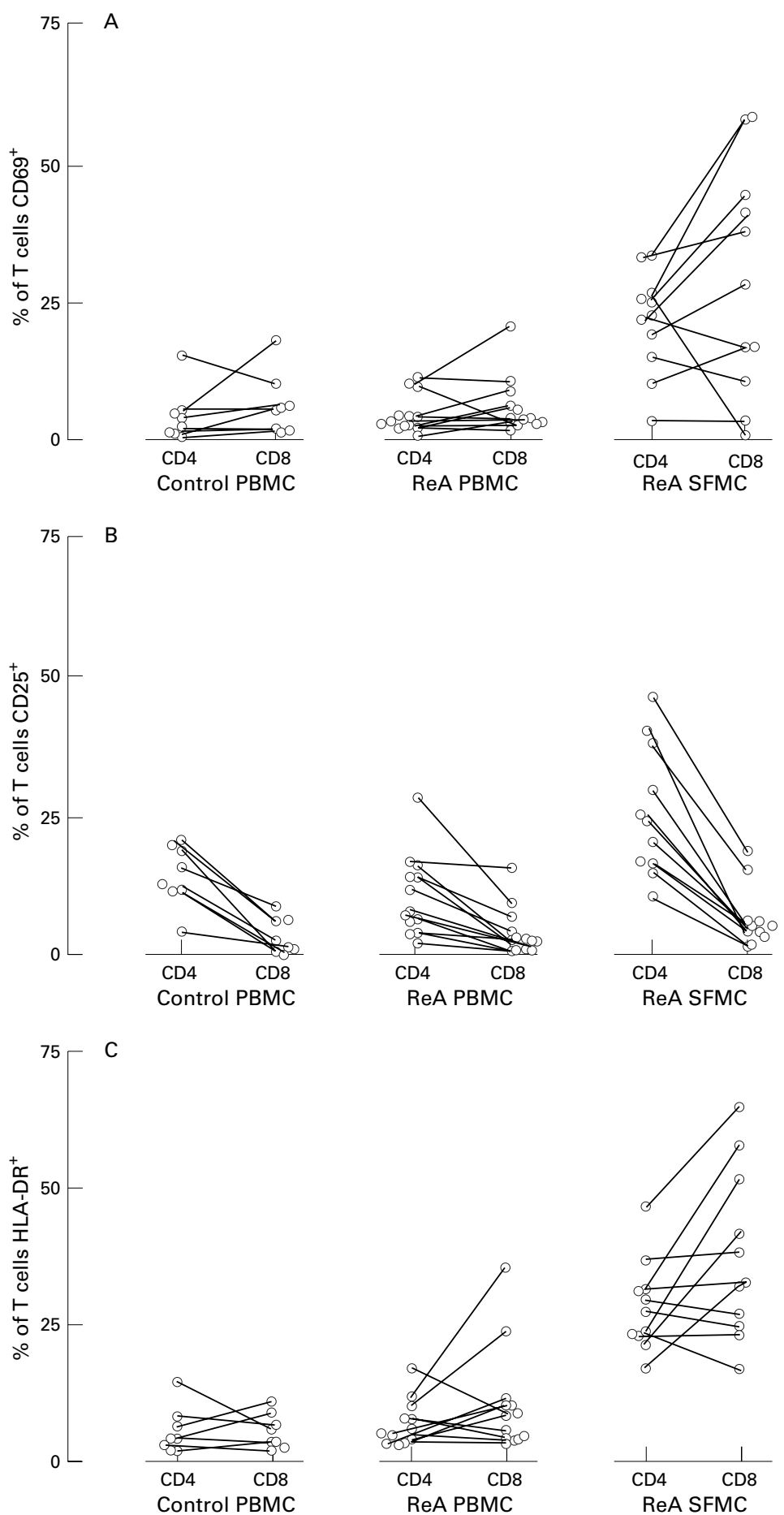

Figure 6 Expression of activation markers by $T$ cell subsets. The percentage of $\mathrm{CD}^{+}$and $C D 8^{+} T$ cells expressing the activation markers $C D 69(A), C D 25(B)$, and $H L A-D R(C)$ is shown. Lines connect the $T$ cell subsets derived from the same person.

of the disease and hence might be expected to be present in increased proportions in the $\mathrm{T}$ cell population of the joint. However, the results presented here (fig 1) show there was no significant difference in the percentages of $\mathrm{CD}^{+}$and $\mathrm{CD} 8^{+} \mathrm{T}$ cells when ReA PB and SF were compared. Interestingly, there was also no correlation between the CD4:CD8 ratios of paired samples of $\mathrm{PB}$ and $\mathrm{SF}$ from $\mathrm{ReA}$ patients, demonstrating that the population of $T$ cells that has migrated into the inflamed joint is not just a reflection of the circulating $\mathrm{T}$ cells, and that other factors must be affecting the numbers of a particular subset of $T$ cells that are present at an inflammatory site, for example, selective migration, proliferation or death within the joint. When the percentages of $\mathrm{TCR} \alpha \beta^{+}$and $\mathrm{TCR} \gamma \delta^{+} \mathrm{T}$ cells were compared, no significant differences were found between ReA PB and ReA SF (fig 2). Hence, although $\mathrm{TCR} \gamma \delta^{+} \mathrm{T}$ cells have been shown to proliferate in response to yersinia in vitro, ${ }^{22}{ }^{23}$ if this is occurring in vivo it is not reflected by an accumulation of these cells in the joint.

An in vitro model of transendothelial migration has been established, ${ }^{24}$ in which cells can migrate through human umbilical vein endothelial cells (HUVECs) into collagen gels from where they can be extracted and their phenotype determined. In this assay, $\mathrm{CD} 8^{+}$and $\mathrm{TCR} \gamma \delta^{+} \mathrm{T}$ cells showed increased migration compared with $\mathrm{CD} 4^{+} \mathrm{T}$ cells. If this is also the case for in vivo migration of $\mathrm{T}$ cells out of the circulation and into the joint, you would expect to find increased proportions of these cells in the SF. As no increase in the proportion of TCR $\gamma \delta^{+} \mathrm{T}$ cells or $\mathrm{CD}^{+} \mathrm{T}$ cells was seen, this may imply that $\mathrm{CD} 4^{+} \mathrm{T}$ cells are being preferentially recruited to the joint, or alternatively, that these cells are proliferating within the joint.

This study demonstrates increased numbers of CD45RO ${ }^{+} \mathrm{T}$ cells in the SF of ReA patients compared with their PB (fig 3), which is in agreement with two other studies ${ }^{25} 26$ that investigated $\mathrm{CD} 45$ expression on $\mathrm{CD}^{+} \mathrm{T}$ cells isolated from ReA SF. Figure 4 shows that there were differences in CD45RA and $\mathrm{CD} 45 \mathrm{RO}$ expression on $\mathrm{CD} 4^{+}$and $\mathrm{CD}^{+}{ }^{+} \mathrm{T}$ cell subsets; more of the $\mathrm{CD}_{4} 5 \mathrm{RO}^{+} \mathrm{T}$ cells were in the $\mathrm{CD}^{+} \mathrm{T}$ cell population while a higher proportion of the $\mathrm{CD}^{+} \mathrm{T}$ cells still expressed CD45RA. This may indicate that it is mainly the $\mathrm{CD} 4^{+} \mathrm{T}$ cell population that has encountered antigen, either within the joint or before migrating there. However, expression of the CD45 isoforms, and the correlation of this with a memory phenotype has not been extensively studied for $\mathrm{CD}^{+} \mathrm{T}$ cells. ${ }^{27-29}$ Also, further experiments using the in vitro model of migration through HUVECs into collagen gels, have shown that the majority of $\mathrm{T}$ cells that migrate are $\mathrm{CD} 45 \mathrm{RO}^{+}$, but some $\mathrm{CD} 45 \mathrm{RA}^{+}$ cells within both $\mathrm{CD}^{+}$and $\mathrm{CD}^{+} \mathrm{T}$ cell subsets can also migrate. ${ }^{24}{ }^{30}$ These results have been corroborated in an in vivo model of inflammation and transendothelial migration. Cells that have migrated into skin blisters overlying PPD induced delayed type hypersensitivity responses that can be harvested and their phenotype and function assessed. In these experiments, most cells found in the blisters are CD $45 \mathrm{RO}^{+31}$; however the percentage of $T$ cells positive for this putative memory marker does increase over time, as does the mean fluorescence intensity of CD45RO staining, suggesting further maturation of the memory phenotype of the $\mathrm{T}$ cells within the site of inflammation. ${ }^{32}$ Hence, the presence of mainly CD45RO ${ }^{+} \mathrm{T}$ cells in the SF of ReA patients may be a result of the selective migration of $\mathrm{T}$ cells with a particular phenotype, but 
further priming of $\mathrm{T}$ cells within the joint cannot be discounted.

A significant number of $T$ cells isolated from the SF of ReA patients expressed activation markers when compared with PB $\mathrm{T}$ cells (fig 5). When expression of activation markers was analysed in the $\mathrm{CD} 4^{+}$and $\mathrm{CD} 8^{+} \mathrm{T}$ cell subsets (fig 6), $\mathrm{CD}^{+} \mathrm{T}$ cells are found to express the early and late activation markers, CD69 and HLA-DR; however very few were CD $25^{+}$. In contrast, $\mathrm{CD} 4^{+} \mathrm{T}$ cells were found to express IL $2 R \alpha$. The presence of IL $2 \mathrm{R} \alpha$ on the $\mathrm{CD} 4^{+} \mathrm{T}$ cell population may explain the ease by which these $\mathrm{T}$ cells are cloned in vitro, with addition of exogenous IL2, from the SF of ReA patients. However, expression of CD25 does not necessarily indicate the presence of a functional high affinity IL2 receptor, which also requires $\beta$ and $\gamma$ subunits. $^{33}$

In a similar study conducted on $\mathrm{T}$ cells isolated from the SF of rheumatoid arthritis (RA) patients, $\mathrm{CD}^{+} \mathrm{T}$ cells were found to express the activation markers CD69, HLADR, and VLA-1, but not CD25. ${ }^{15}$ This pattern of expression of activation markers is comparable to that found on $\mathrm{ReA} S \mathrm{SF}$ derived $\mathrm{CD} 8^{+} \mathrm{T}$ cells. Interestingly, RA SF derived $\mathrm{T}$ cells were found to coexpress early and late activation markers (for example, CD69 and HLA-DR). T cells isolated from PPD induced skin blisters were also found to express early and late activation markers, even if the $\mathrm{T}$ cells were analysed only 24 hours after injection of the PPD. This pattern of expression does not occur on $\mathrm{T}$ cells polyclonally stimulated in vitro, and the authors suggested this unusual phenotype may be a result of migration through the endothelium. In the study presented here it is not known if dual expression of early and late activation markers occurs on $\mathrm{T}$ cells isolated from ReA SF as analysis was limited to three surface markers. Further experiments using the in vitro model of migration have shown that CD4 depleted $T$ cells that have migrated through HUVECs contain a higher percentage of $\mathrm{CD} 69^{+}$cells, compared with the initial starting population and those that did not migrate. ${ }^{24}$ As with the in vivo model of migration, it is not known whether this is selective migration of $\mathrm{CD} 69^{+} \mathrm{T}$ cells, or if the process of passing through the endothelium has changed the activation status of the cells. Therefore, the presence of activated $T$ cells within the joint of ReA patients cannot be explained exclusively by stimulation within the joint; expression of activation markers may result in preferential migration of these cells, or the process of migration itself may result in upregulation of activation markers.

An interesting comparison of the activation status of the $T$ cells isolated from ReA SF can be drawn with PB T cells from Bangladeshi patients suffering from a shigella infection. $T$ cells isolated from the $\mathrm{PB}$ of shigellosis patients are reported to have increased proportions of $\mathrm{CD} 4^{+} \mathrm{T}$ cells expressing CD25, and $\mathrm{CD}^{+} \mathrm{T}$ cells expressing HLA-DR, when compared with a healthy population of volunteers. ${ }^{34}$ These results, in conjunction with the study reported here, may imply that the expression of this combination of activation markers on the two $\mathrm{T}$ cell subsets is a reflection of an ongoing immune response to bacterial antigens, whether in the periphery or confined to the joint. $T$ cells isolated from the PB of ReA patients were found to contain more HLA-DR ${ }^{+}$ $\mathrm{T}$ cells compared with $\mathrm{T}$ cells from healthy controls; however there were no significant differences between control and ReA PB in the expression of the other activation markers. These results are not surprising as most ReA patients had suffered from the bacterial infection responsible for initiating the arthritis several weeks before the paired SF and PB samples being collected.

Activated $\mathrm{T}$ cells expressing CD25 are not necessarily involved in actively inducing inflammation; instead several animal models of autoimmune diseases have implicated $\mathrm{CD} 4{ }^{+} \mathrm{CD} 25^{+} \mathrm{T}$ cells in maintaining tolerance and thereby playing a part in limiting disease. ${ }^{35}{ }^{36}$ Thymectomy of B6A mice at day 3 results in spontaneous development of autoimmune diseases, which can be transferred to syngeneic naive mice by $\mathrm{CD}^{+} \mathrm{T}$ cells. Injection of a monoclonal antibody to delete $\mathrm{CD} 25^{+} \mathrm{T}$ cells did not reduce the incidence of the disease in these mice, suggesting the $\mathrm{CD} 25^{+} \mathrm{T}$ cells are not playing a part in causing autoimmune disease. However, treatment of mice thymectomised at day 7 (which would not normally develop disease), or normal mice, with anti-CD25 did induce development of autoimmune disease. ${ }^{35}$ These findings lead the authors to propose that there is a population of $\mathrm{CD}^{+} \mathrm{T}$ cells expressing IL2R $\alpha$, which are $\mathrm{T}$ suppressor cells that are maintaining immune tolerance. Similar conclusions were drawn from experiments conducted in nude BALB/c mice that develop several autoimmune diseases when reconstituted with $\mathrm{T}$ cells depleted of $\mathrm{CD} 4^{+} \mathrm{CD} 25^{+}$cells. $^{36}$ If $\mathrm{CD} 4^{+} \mathrm{CD} 25^{+}$cells are co-transferred autoimmune diseases can be prevented. Hence, in this animal model, it is proposed that the $\mathrm{CD} 4^{+} \mathrm{CD} 25^{+} \mathrm{T}$ cells are helping to maintain self tolerance.

ReA, although lasting several months, usually resolves spontaneously. $\mathrm{CD} 4^{+} \mathrm{CD} 25^{+} \mathrm{T}$ cells are found in the SF of these patients. In contrast RA is a chronic disease and CD $25^{+} \mathrm{T}$ cells are not detectable within the SF. In RA it could be proposed that the lack of $\mathrm{CD} 4^{+} \mathrm{CD} 25^{+}$ $\mathrm{T}$ cells in the joint are preventing self tolerance mechanisms and thereby allowing immune responses against self antigens to occur. Conversely, in $\mathrm{ReA}, \mathrm{CD} 4^{+} \mathrm{CD} 25^{+} \mathrm{T}$ cells are detected in the $\mathrm{SF}$ and a role for these cells may be in limiting the disease.

In conclusion, the results presented here show that both $\mathrm{CD} 4^{+}$and $\mathrm{CD}^{+} \mathrm{T}$ cells are activated in ReA SF; however more $\mathrm{CD}^{+}{ }^{+} \mathrm{T}$ cells express CD25, while more $\mathrm{CD}^{+} \mathrm{T}$ cells are HLA-DR ${ }^{+}$. The presence of activated cells in both $\mathrm{T}$ cell subsets may indicate that both $\mathrm{CD}^{+}$and $\mathrm{CD}^{+} \mathrm{T}$ cells play a part in the pathogenesis of joint inflammation in ReA. Whether they are involved in initiating the inflammation or contributing to the resolution of the disease is still unclear. Functional studies on the $T$ cell subsets, such as analysing the 
cytokines produced by these two subsets, may further dissect their respective roles.

We thank Dr D Carruthers, Dr G Kitas, and the staff of Queen Elizabeth Medical Centre, Birmingham, and Addenbrooke's
Hospital, Cambridge, for providing SF and PB samples.

This work was supported by the Arthritis and Rheumatism This work was supported by the Arthritis and Rheun
Council (UK) and the Medical Research Council (UK).

1 Weinberger HW, Ropes MW, Kolka JP, Bauer W. Reiter's syndrome, clinical and pathologic observations. A long syndrome, clinical and pathologic observations. A long 91.

2 Nordstrom D, Konttinen YT, Bergroth V, Leirisalo-Repo M. Synovial fluid cells in Reiter's syndrome. Ann Rheum Dis $1985 ; 44: 852-6$

3 Gaston JSH, Life PL, Granfors K, Merilahti PR, Bailey L, Consalvey S, et al. Synovial T lymphocyte recognition of organisms that trigger reactive arthritis. Clin Exp Immunol 1989;76:348-53.

4 Sieper J, Braun J, Wu P, Kingsley G. T cells are responsible for the enhanced synovial cellular immune response to triggering antigen in reactive arthritis. Clin Exp Immunol 1993;91:96-102.

5 Hammer RE, Maika SD, Richardson JA, Tang J-P, Taurog JD. Spontaneous inflammatory disease in transgenic rats expressing HLA-B27 and human $\mathrm{b}_{2} \mathrm{~m}$ : an animal model of HLA-B27-associated human disorders. Cell 1990;63: HLA-B27- $1099-12$.

6 Breban M, Ferdandez-Sueiro JL, Richardson JA, Hadavand RR, Maika SD, Hammer RE, et al. T cells, but not thymic RR, Maika SD, Hammer RE, et al. T cells, but not thymic exposure to HLA-B27, are required for the inflammatory disease of

7 Hermann E, Yu DT, Meyer-zun-Buschenfelde KH, Fleischer B. HLA-B27-restricted CD8 T cells derived from synovial fluids of patients with reactive arthritis and ankylosing spondylitis. Lancet 1993;342:646-50.

8 Duchmann R, May E, Ackermann B, Goergen B, Mayer zum Büschenfelde K-H, Märker-Hermann E. HLA-B27restricted cytotoxic $\mathrm{T}$ lymphocyte responses to arthritogenic enterobacteria or self-antigens are dominated by closely related TCRBV gene segments. A study in patients with reactive arthritis. Scand Immunol 1996;43:101-8.

9 Hassell AB, Pilling D, Reynolds D, Life PF, Bacon PA, Gaston JSH. MHC restriction of synovial fluid lymphocyte ton JSH. MHC restriction of synovial fluid lymphocyte Absence of a class I-restricted response. Clin Exp Immunol 1992;88:442-7.

10 Viner NJ, Bailey LC, Life PF, Bacon PA, Gaston JSH. Isolation of Yersinia-specific $T$ cell clones from the synovial fluid membrane and synovial fluid of a patient with reactive arthritis. Arthritis Rheum 1991;34:1151-7.

11 Hassell AB, Reynolds DJ, Deacon M, Gaston JSH, Pearce $\mathrm{JH}$. Identification of T-cell stimulatory antigens of Chlamydia trachomatis using synovial fluid-derived $\mathrm{T}$ cell clones. Immunology 1993;79:513-19.

12 Gaston JSH, Deane KHO, Jecock RM, Pearce JH. Identification of 2 chlamydia-trachomatis antigens recognised by synovial-fluid T-cells from patients with chlamydia-induced reactive arthritis. J Rheumatol 1996;23:130-6.

13 Deane KHO, Jecock RM, Pearce JH, Gaston JSH. Identification and characterisation of a DR4-restricted T cell epitope within chlamydia heat shock protein 60. Clin Exp Immunol 1997; 109:439-45.

14 Sieper J, Braun J. Pathogenesis of spondylarthropathies. Persistent bacterial antigen, autoimmunity, or both? Persistent bacterial antigen, aut

15 Iannone F, Corrigall VM, Kingsley GH, Panayi GS Evidence for the continuous recruitment and activation of $\mathrm{T}$ cells into the joints of patients with rheumatoid arthritis. Eur J Immunol 1994;24:2706-13.

16 Bajorath J, Aruffo A. Molecular model of the extracellular lectin-like domain in CD69. J Biol Chem 1994;269: 32457-63.
17 Biselli R, Matricardi PM, D' Amelio R, Fattorossi A. Multiparametric flow cytometric analysis of the kinetics of surface molecule expression after polyclonal activation of human peripheral blood T lymphocytes. Scand J Immunol 1992;35:439-47.

18 Akbar AN, Terry L, Timms A, Beverley PC, Janossy G. Loss of CD45R and gain of UCHL1 reactivity is a feature of primed T cells. J Immunol 1988;140:2171-8.

19 Konttinen YT, Nordström D, Bergroth V, Leirisalo-Repo M, Skrifvars B. Cell-mediated immune response in the diseased joints in patients with reactive arthritis. Scand J Immunol 1986;23:685-91.

20 Dominguez O, Coto E, Martinez-Naves E, Choo SY, Lopez-Larrea C. Molecular typing of HLA-B27 alleles. Immunogenetics 1992;36:277-82.

21 Amadori A, Zamarchi R, De Silvestro G, Forza G, Cavatton G, Daniell GA, et al. Genetic control of the CD4/CD8 T-cell ratio in humans. Nature Med 1995;1:1279-83.

22 Young JL, Goodall JC, Beacock-Sharp H , Gaston JSH. Human gd $\mathrm{T}$ cell recognition of Yersinia enterocolitica. Immunology 1997;91:503-10.

23 Hermann E, Ackermann B, Duchmann R, Meyer zum Buschenfelde KH. Synovial fluid MHC-unrestricted gamma delta-T lymphocytes contribute to antibacterial and anti-self cytotoxicity in the spondylarthropathies. Clin Exp Rheum 1995;13:187-91.

24 Galéa P, Brezinschek R, Lipsky PE, Oppenheimer-Marks N. Phenotypic characterisation of CD4-/alpha beta TCR+ and gamma delta TCR+ T cells with a transendothelial migratory capacity. J Immunol 1994;153:529-42.

25 Matthews N, Emery P, Pilling D, Akbar A, Salmon M. Subpopulations of primed T helper cells in rheumatoid arthritis. Arthritis Rheum 1993;36:603-7.

26 Braun J, Grolms M, Sieper J. Three-colour flowcytometric examination of CD4/CD45 subsets reveals no differences in peripheral blood and synovial fluid between patients with reactive arthritis and rheumatoid arthritis. Clin Exp Rheum 1994;12:17-22.

27 Beverley PC, Daser A, Michie CA, Wallace DL. Functional subsets of T cells defined by isoforms of CD45. Biochem Soc Trans 1992;20:184-7.

28 Warren HS, Skipsey LJ. Loss of activation-induced CD45RO with maintenance of CD45RA expression during prolonged culture of $\mathrm{T}$ cells and NK cells. Immunology 1991;74:78-85.

29 Merkenschlager M, Beverley PC. Evidence for differential expression of CD45 isoforms by precursors for memorydependent and independent cytotoxic responses: human CD8 memory CTLp selectively express CD45RO (UCHL1). Int Immunol 1989;1:450-9.

30 Brezinschek RI, Lipsky PE, Galea P, Vita R, OppenheimerMarks N. Phenotypic characterisation of CD4+ T cells that exhibit transendothelial migratory capacity. J Immunol exhibit transendothe

31 Pitzalis C, Kingsley GH, Covelli M, Meliconi R, Markey A, Panayi GS. Selective migration of the helper-inducer memory $\mathrm{T}$ cell subset: confirmation by in vivo cellular kinetic studies. Eur J Immunol 1991;21:369-76.

32 Salmon M, Gaston JSH. The role of T-lymphocytes in rheumatoid arthritis. Br Med Bull 1995;51:332-45.

33 Weissman AM, Harford JB, Svetlik PB, Leonard WL, Depper JM, Waldmann TA, et al. Only high affinity receptors for interleukin-2 mediate internalisation of ligand. Proc Natl Acad Sci USA 1986;83:1463-6.

34 Islam D, Bardhan PK, Lindberg AA, Christensson B. Shigella infection induces cellular activation of $\mathrm{T}$ and $\mathrm{B}$ cells and distinct species-related changes in peripheral blood lymphocyte subsets during the course of the disease. Infect Immun 1995;63:2941-9.

35 Taguchi O, Takahashi T. Administration of antiinterleukin-2 receptor a antibody in vivo induces localised autoimmune disease. Eur J Immunol 1996;26:1608-12.

36 Sakaguchi S, Sakaguchi N, Asano M, Itoh M, Toda M. Immunologic self-tolerance maintained by activated $\mathrm{T}$ cells expressing IL-2 receptor a-chains (CD25). Breakdown of a single mechanism of self-tolerance causes various autoimmune diseases. J Immunol 1995;155:1151-64. 